\title{
Procuring Plant Services for Ecological and Human Well Being
}

\author{
K. Saraswathi* $\dagger$ and K. Selvam** \\ *Department of Botany and National Centre of Excellence (MHRD), Thiagarajar College, Madurai -625 009, \\ Tamil Nadu, India \\ **PG \& Research Department of Botany, Thiagarajar College, Madurai- 625 009, Tamil Nadu, India \\ $\dagger$ Corresponding author: K. Saraswathi; krish.saras31@gmail.com
}

Nat. Env. \& Poll. Tech.

Website: www.neptjournal.com

Received: 16-08-2020

Revised: $30-09-2020$

Accepted: 16-10-2020

Key Words:

Ecosystem services

Native

Exotic

Carbon sequestration

\begin{abstract}
Ecosystem services offered by two native tree species viz. Azadirachta indica, Morinda tinctoria, and four exotic species viz. Tamarindus indica, Prosopis juliflora, Leucaena leucocephala, and Ipomoea carnea in the Mathippanur village of Madurai district, Tamil Nadu, India were assessed to augment their valuable ecosystem services and to get the management strategy for sustainable use. The selected plant species provide economic benefit through their products, regulating soil health, sequestering carbon, and supporting nests of animals. However, they cause discomfort to the associated vegetation and human beings. Both native and exotic species play a crucial role in the ecosystem and the removal of exotic species will lead to disturbance in the ecosystem resilience. For sustainable management, mixed plantations of tree species can be raised in barren and fallow lands. The plantations will aid in monetary support to the local inhabitants, people's participation in resource management and conservation, and effective use of land and tree services.
\end{abstract}

\section{INTRODUCTION}

Human subsistence on Earth is impossible without the services of natural ecosystems (Daily 1997). Ecosystems play an important role in climate regulation, water circulation, plant reproduction, and soil nutrient dynamics (Costanza et al. 1997). These valuable functions of ecosystems are often termed ecosystem services. The ecosystem services include the delivery, provision, production, protection, or maintenance of a set of goods and services (Chee 2004). Ecosystem services include both goods and services which have a direct and indirect influence on human well-being (Daily 1997). Millennium Ecosystem Assessment (MEA 2003) also recognized the role of ecosystem services in human society.

Beyond whole ecosystem valuation, services of selected trees and shrubs on human well-being are evaluated as this biomass becomes the major source of many goods for human consumption, energy production, and genetic resources. They regulate microclimate and pollution. They also provide refuge sites and habitats for the reproduction of many other organisms. They play an inevitable role in biogeochemical cycles that interconnect air, soil, and water (Roeland et al. 2019). They also maintain the physical and mental health of human beings through their aesthetic value, spiritual enrichment, and recreation (de Groot et al. 2002).

The composition of the plant community has an influence on regular services in an ecosystem (Bennett et al. 2009).
The complex ecosystem has both native species and new arrivals and each of the species play a critical role in ecosystem function. Some of the introduced species serve as a major food source (Pimentel et al. 2001). The management of exotic species and intensification of services rendered by the plant species require a methodical understanding of their functions in the ecosystem. Hence, a study was performed to assess the provisional, regulating, supporting services, and disservices offered by selected native and exotic plant species viz., Azadirachta indica, Morinda tinctoria, Tamarindus indica, Prosopis juliflora, Leucaena leucocephala, and Ipomoea carnea, and to augment their commercial and ecological benefits.

\section{MATERIALS AND METHODS}

\section{Study Area and Climate}

The study was performed during June 2015 - May 2016 in a village called Mathippanur in Thirumangalam Taluk of Madurai district, Tamil Nadu, India (Fig.1). It is located at $9.79878^{\circ} \mathrm{N}$ latitude and $77.851879^{\circ} \mathrm{E}$ longitude. It lies above 35 to $52 \mathrm{~m}$ above mean sea level. The climate is dry and hot with rains between October to December. The temperature during summer reaches a maximum of $40.0^{\circ} \mathrm{C}$ and a minimum of $26.3^{\circ} \mathrm{C}$. Winter temperature ranges between $29.6^{\circ} \mathrm{C}$ and $18.0^{\circ} \mathrm{C}$. The average annual rainfall is about 85 $\mathrm{cm}$. According to the Census of India, in 2011, the village 


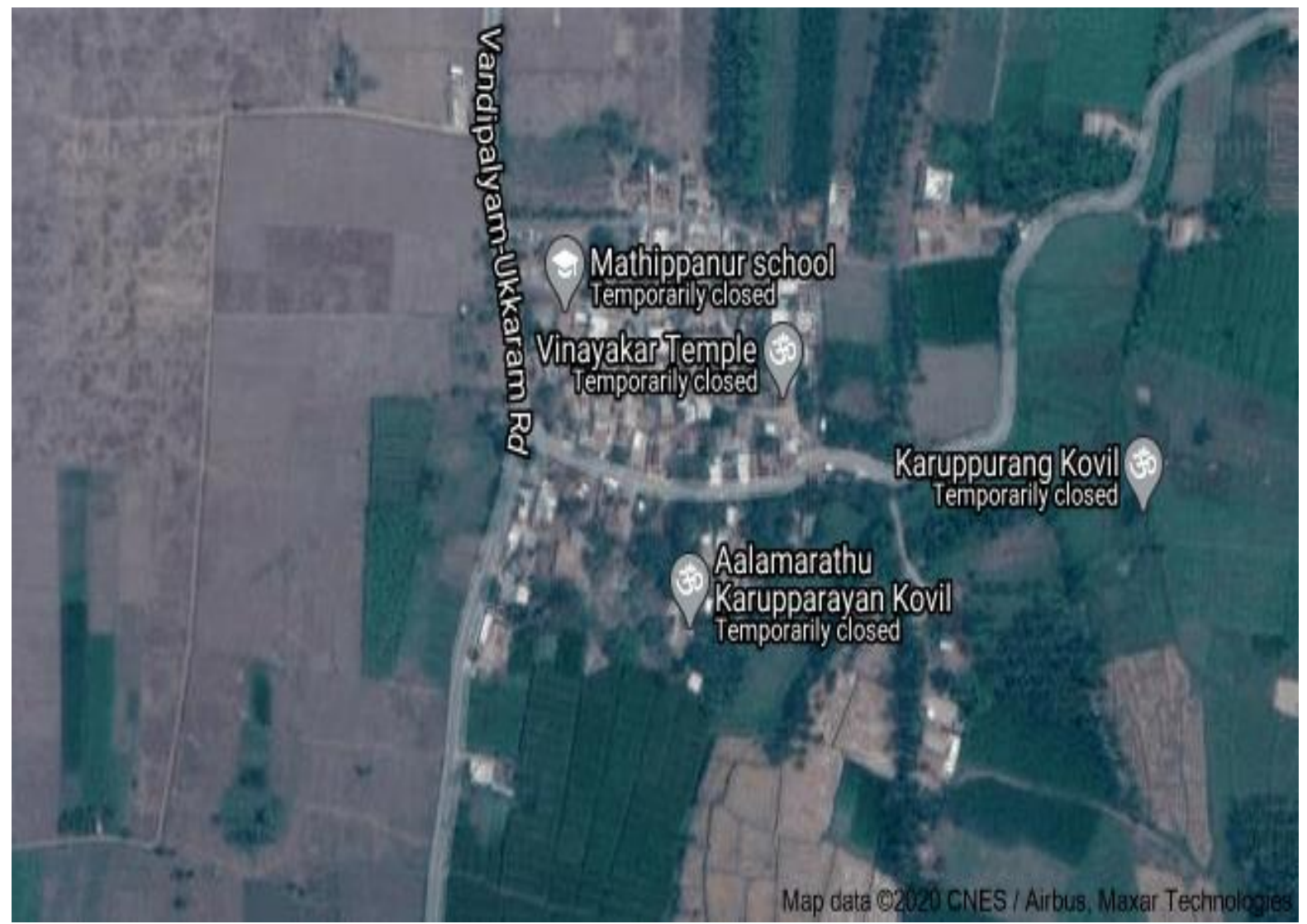

Source: Google Satellite map at https://www.google.com/maps/place/Mathipanur,+Tamil+Nadu+638454/@ 11.4058688,77.2415686,768m/data$=! 3 \mathrm{~m} 1 ! 1 \mathrm{e} 3 ! 4 \mathrm{~m} 5 ! 3 \mathrm{~m} 4$ ! $1 \mathrm{~s} 0 \times 3 \mathrm{ba} 91 \mathrm{f} 74 \mathrm{ff} 262283: 0 x 2978 \mathrm{~d} 785 \mathrm{c} 9 \mathrm{fd} 1 \mathrm{a} 7 \mathrm{a} ! 8 \mathrm{~m} 2 ! 3 \mathrm{~d} 11.4057563$ ! $4 \mathrm{~d} 77.2437483$

Fig. 1: Satellite map showing the study area Mathippanur village in Thirumangalam Taluk, Madurai District, Tamil Nadu, India

had a total adult population of 2008 with 984 males and 1024 females.

\section{Socio-Economic Status of the Study Area}

People in the study area are farmers and only a few who belong to the 20-30 years' age group are educated. Agriculture is their major occupation. Each family has 10-15 acres of own land for cultivation. They cultivate cotton, millets, and Sorghum in their fields. They move to nearby towns for their earnings during periods without sufficient rainfall.

\section{Study Site Selection}

The study sites with selected native and exotic plant species viz., A. indica, T. indica, M. tinctoria, P. juliflora, $L$. leucocephala, and I. carnea are found distributed in fallow lands and riparian zone of Mathippanur village. They can grow in loamy to sandy loamy soil. The selected plant species are distributed in a scattered manner. The age of the selected plants is 5-10 years.
A. indica and $M$. tinctoria are indigenous tree species. The native of $T$. indica is Tropical Africa, $P$. juliflora is North America, L. leucocephala is Southern Mexico and Northern Central America, and I. carnea is between Florida and Argentina.

\section{Estimation of Plant Growth Parameters}

Different plant growth parameters namely tree heights, girths, and densities were estimated. The biomass of tree species was calculated using the regression technique described as 'dimension analysis of woody plot' by Whittaker (1961) and 'allometry' by Chave et al. (2005). The carbon content of plant samples was estimated by using the wet acid digestion method (Jackson 1973).

\section{Cost-Benefit Analysis}

The productive services of selected native and exotic species were estimated based on the economic valuation of goods obtained from them. To collect this economic valuation, a 
semi-structured interview was conducted with residents at Mathippanur village. The economic benefits derived from various products of selected plant species were estimated through the adjusted market price method (Godoy et al. 1993).

\section{Herbaceous Density Analysis}

The herbaceous community structure was analyzed by using the quadrat method.

\section{Estimation of Soil Parameters}

Soil bulk density was analyzed using a soil core method (Anderson \& Ingram 1993). Soil moisture was determined by the gravimetric method (Jackson 1973). Soil respiration was measured by using the method described by Anderson (1982). Soil microbial biomass was determined in fresh soil by the Chloroform fumigation extraction technique (Vance et al. 1987).

\section{Nest Analysis}

The supporting service of the trees was analyzed by counting the number of nests made by different animals.

\section{Statistical Analysis}

One-way ANOVA was performed to find the significant mean value differences of selected parameters among the selected plant species using SPSS16.0. Post-hoc analysis was performed using Tukey's HSD at $\mathrm{p}=0.05$. Regression equations were also obtained using SPSS16.0.

\section{RESULTS AND DISCUSSION}

\section{Density and Growth Parameters of Selected Plant Species}

In the study area, $P$. juliflora was the most predominant species (Fig. 2) in terms of density. There were totally around 25 trees of $P$. juliflora found in an acre. This is because of the aggressive and invasive potential of $P$. juliflora when compared to other species. It tends to replace the native vegetation through encroachment (Bokrezion 2008). The other exotic plant $L$. leucocephala becomes an aggressive invader in Mexico and the Philippines (Orwa et al. 2009). However, in the present study areas, it is not as invasive as P. juliflora.

An exotic species L. leucocephala was significantly tall

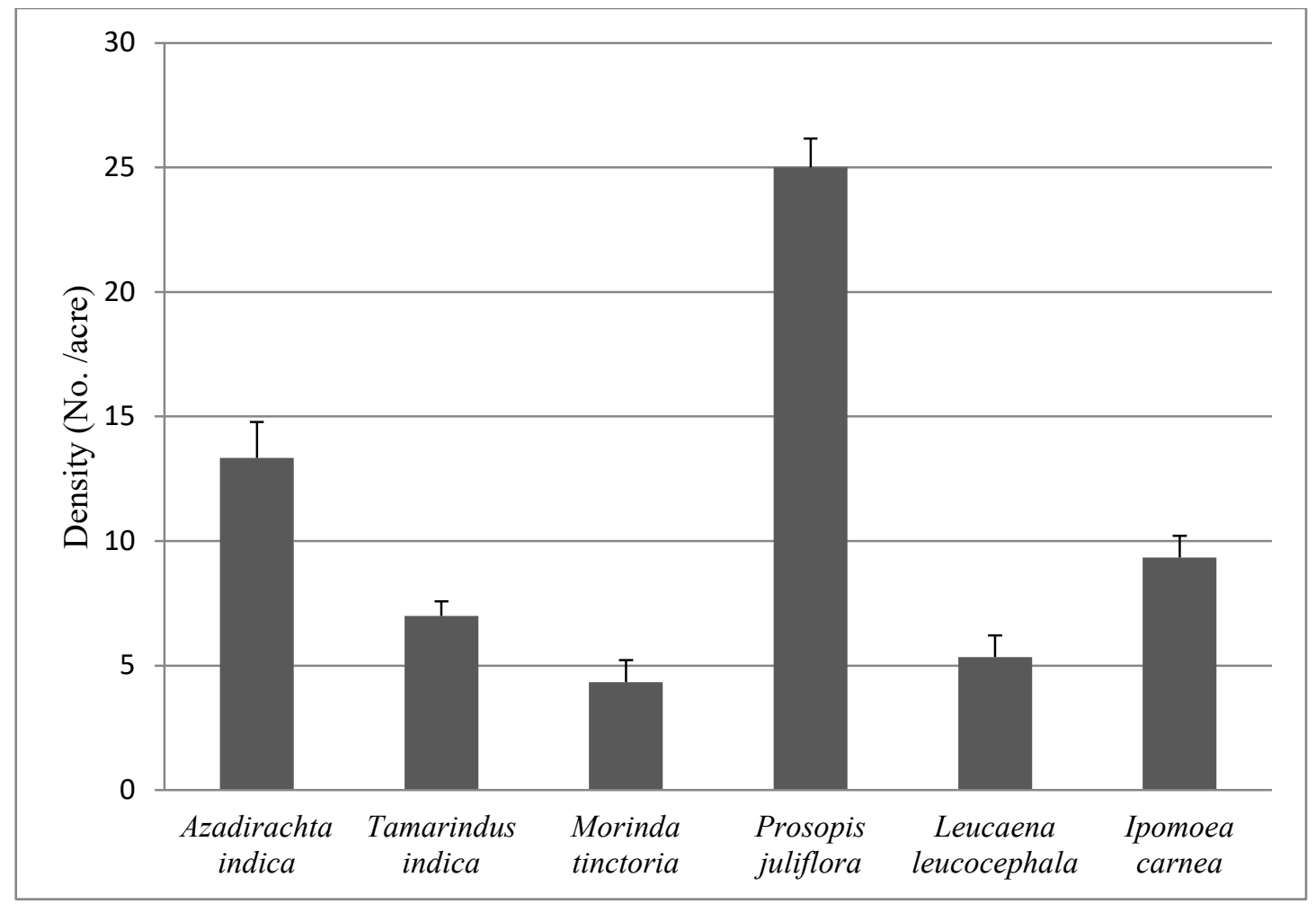

Fig. 2: Density of selected native and exotic plant species in Mathippanur Village, Thirumangalam Taluk, Madurai District, Tamil Nadu, India Values - Mean $\pm \mathrm{SE}$ 
$(2.17 \pm 0.17 \mathrm{~m})$ and has a large diameter $(58.05 \pm 2.35 \mathrm{~cm})$ when compared to other species (Table 1). Earlier reports agreed that it can reach an average of $5 \mathrm{~m}$ height and a bole diameter of 10-50 cm (Orwa et al. 2009).

The average biomass of $T$. indica $(968.86 \pm 88.49 \mathrm{~kg})$ was incomparable with other species and it yielded significantly larger biomass than other native and exotic plant species. Next to it, A. indica produced a large amount of biomass $(412.43 \pm 46.76 \mathrm{~kg})$. Biomass accumulation in a tree depends on the nature of the species and its density. In the present study, the density of $T$. indica was comparatively lesser than A. indica. This could be one of the reasons for its higher biomass yield per acre.

\section{Provisioning Services}

Domestic use of products: Certain products obtained from the selected plants are used for domestic purposes. They indirectly reduced the expenditure of food, medicine, and cooking fuel at the household-level (Table 2). A. indica has an alkaloid Azadiractin. Branch sticks of $A$. indica are used as toothbrushes. Dentists find twigs of $A$. indica effective in preventing periodontal disease. The leaves have high medicinal value and are used as germicidal agents. The leaves are also used to repel 300 different insect species (Ogah et al. 2011). The seed cake is used to control insects as well as fertilizers.

T. indica offers commercial as well as household-level benefits. Due to its variety of productive services, it is considered as one of the important agroforestry plant species. It is rich in vitamin B (thiamine and niacin) as well as has a small amount of carotene and vitamin $\mathrm{C}$. Thus its flowers, leaves, and seeds are eaten and used to prepare a variety

Table 1: Growth parameters of selected native and exotic plant species in Mathippanur Village, Thirumangalam Taluk, Madurai District, Tamil Nadu, India

\begin{tabular}{|lllll|}
\hline S. No. & Name of the plant species & Height $(\mathrm{m})$ & Diameter $(\mathrm{cm})$ & Biomass $(\mathrm{kg})$ \\
\hline 1 & Azadiarachta indica A. Juss. & $1.78 \pm 0.04^{\mathrm{bc}}$ & $20.43 \pm 3.31^{\mathrm{ab}}$ & $412.43 \pm 46.76^{\mathrm{b}}$ \\
2 & Tamarindus indica L. & $1.95 \pm 0.07^{\mathrm{cd}}$ & $20.56 \pm 1.72^{\mathrm{ab}}$ & $968.86 \pm 88.49^{\mathrm{c}}$ \\
3 & Morinda tinctoria Roxb. & $1.16 \pm 0.03^{\mathrm{a}}$ & $7.97 \pm 0.55^{\mathrm{a}}$ & $92.42 \pm 6.81^{\mathrm{a}}$ \\
4 & Prosopis juliflora (SW.) DC. & $1.53 \pm 0.08^{\mathrm{ab}}$ & $6.47 \pm 0.63^{\mathrm{a}}$ & $118.86 \pm 9.46^{\mathrm{a}}$ \\
5 & Leucaena leucocephala (Lam.) de Wit & $2.17 \pm 0.17^{\mathrm{d}}$ & $58.05 \pm 2.35^{\mathrm{b}}$ & $76.14 \pm 9.95^{\mathrm{a}}$ \\
6 & Ipomoea carnea Jacq. & $1.34 \pm 0.06^{\mathrm{a}}$ & $1.58 \pm 0.70^{\mathrm{a}}$ & $28.71 \pm 3.57^{\mathrm{a}}$ \\
\hline
\end{tabular}

Values - Mean \pm SE. Different letters indicate significant differences among the mean values within a column at $\mathrm{p}<0.05$ level

Table 2: Provisioning services offered by selected native and exotic plant species at the house-hold level in Mathippanur Village, Thirumangalam Taluk, Madurai District, Tamil Nadu, India

\begin{tabular}{|c|c|c|c|}
\hline S. No. & Name of the Plant species & Parts used & Uses \\
\hline \multirow[t]{3}{*}{1} & \multirow[t]{3}{*}{ Azadiarachta indica A. Juss. } & Leaves & Medicine, Mosquito repellent, Soap \\
\hline & & Wood and branches & Firewood \\
\hline & & Branch Sticks & Toothbrush \\
\hline \multirow[t]{3}{*}{2} & \multirow[t]{3}{*}{ Tamarindus indica $\mathrm{L}$. } & Wood and branches & Firewood \\
\hline & & Flowers & Food (Soup) \\
\hline & & Seeds & Food, Medicine \\
\hline \multirow[t]{3}{*}{3} & \multirow[t]{3}{*}{ Morinda tinctoria Roxb. } & Wood and branches & Firewood \\
\hline & & Leaves & Medicine \\
\hline & & Bark & Rope for roof making \\
\hline \multirow[t]{2}{*}{4} & \multirow[t]{2}{*}{ Prosopis juliflora (SW.) DC. } & Thorny branches & Fence \\
\hline & & Fruit & Fodder \\
\hline \multirow[t]{3}{*}{5} & \multirow{3}{*}{$\begin{array}{l}\text { Leucaena leucocephala (Lam.) } \\
\text { de Wit }\end{array}$} & Wood and branches & Firewood \\
\hline & & Branches & Fence \\
\hline & & Leaves & Fodder \\
\hline \multirow[t]{2}{*}{6} & \multirow[t]{2}{*}{ Ipomoea carnea Jacq. } & Leaves & Roof making \\
\hline & & Branches & Fence \\
\hline
\end{tabular}


of dishes marketed worldwide such as sauces, syrups, and processed foods. In the present study area, people reported that it is used to nourish malnourished children.

The leaves of M. tinctoria are used as medicine for scabies, hip pain, and joint pain. Rope prepared from the bark of $M$. tinctoria is used to tie roof thatches.

$P$. juliflora and L. leucocephala fruit pods are the major sources of fodder for the cattle. Their branches are used as a fence for houses and cattle sheds. I. carnea branches are also used as fencing material. Their leaves are laid under thatched roofs to get a cooling effect. Wood and branches of $A$. indica, T. indica, M. tinctoria, and L. leucocephala are used as fuelwood. A. indica, T. indica, and L. leucocephala offer tremendous services to ecosystem health, human health, and human sustenance (Orwa et al. 2009).

Commercial benefits from the products: The major occupation of people in the study area is agriculture. Due to erratic rainfall, farmers do not get money from agriculture throughout the year. So they avail the productive services of the plants for their livelihood. Although the commercial benefits offered by these plants are seasonal, they became one of the alternate sources of their economy. The products of these plants are used as such or processed into different forms.

T. indica produced significantly larger biomass in an acre $(6782.00 \pm 559.37 \mathrm{~kg} / \mathrm{acre})$ than other species (Fig. 3). It was followed by $A$. indica $(5499.00 \pm 599.24 \mathrm{~kg} / \mathrm{acre})$. These plant species support the livelihoods of several groups of people namely landowners, tenants, laborers, and people who help in transportation (Table 3 and 4). People who owned fallow land with exotic, invasive $P$. juliflora trees derived a substantial amount of money (INR 10,000) (US\$ 132.65) without any investment. The charcoal production from $P$. juliflora provides a considerable monetary benefit to local people (Ilukor et al. 2016).

\section{Regulating Services}

Carbon sequestration capacity: Woody plant proliferation has been proposed as a significant terrestrial sink for atmospheric $\mathrm{CO}_{2}$ (Scholes \& Noble 2001) and to mitigate climate changes. Almost all the selected species had carbon content in 3/4th of their biomass. Carbon storage capacity in

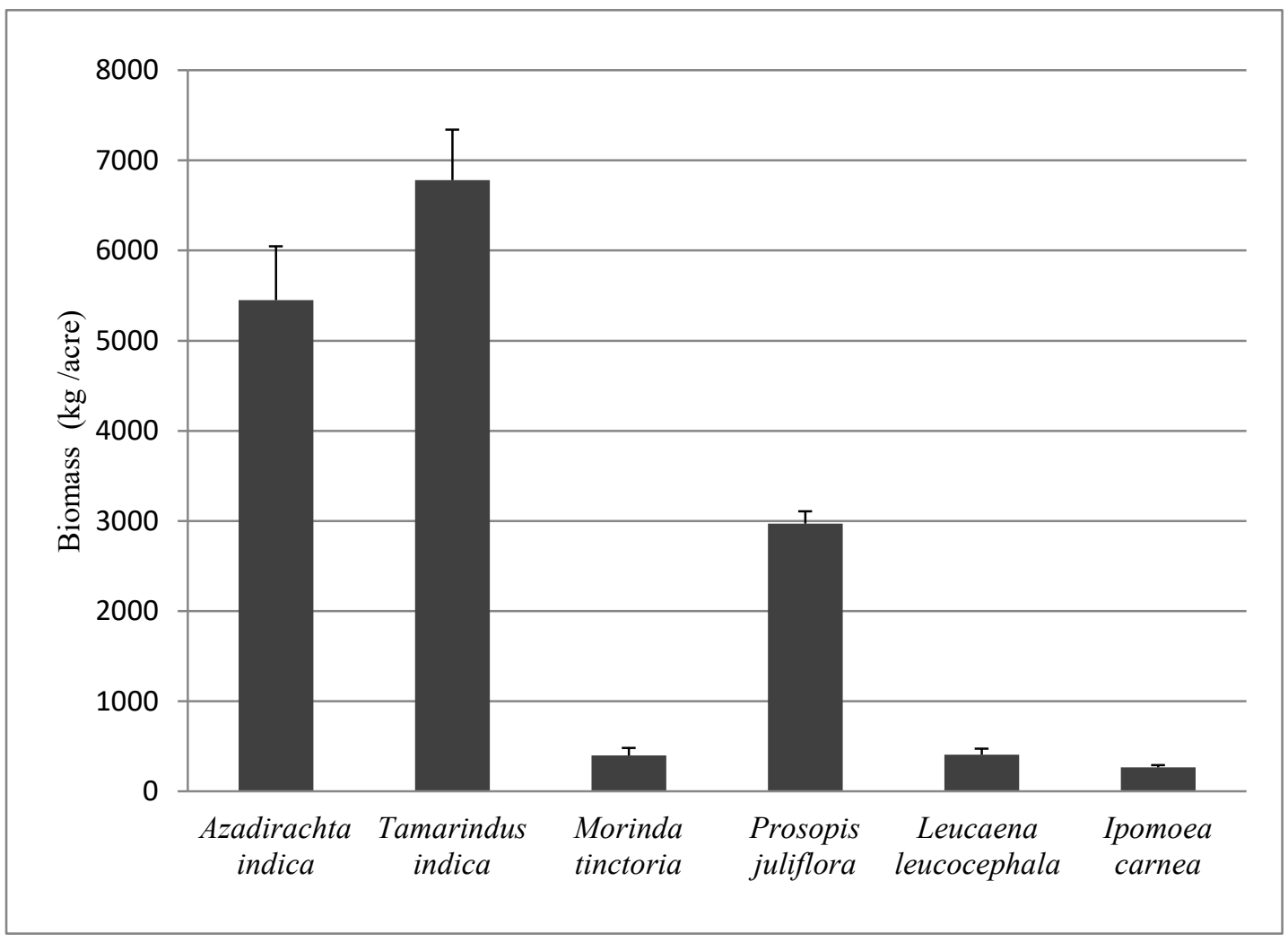

Fig. 3: Biomass (kg / acre) of selected native and exotic plant species in Mathippanur Village, Thirumangalam Taluk, Madurai District, Tamil Nadu, India

Values - Mean \pm SE 
K. Saraswathi and K. Selvam

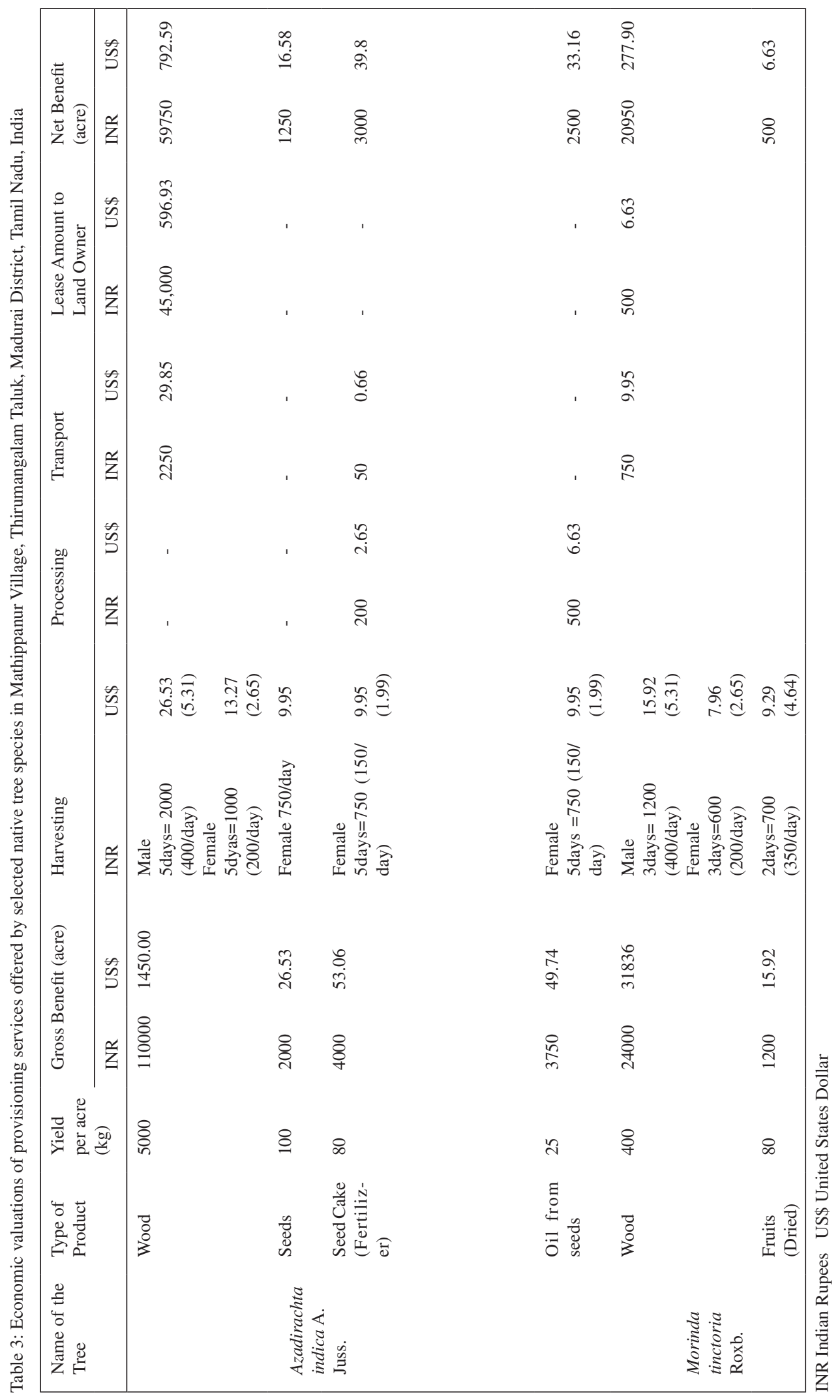




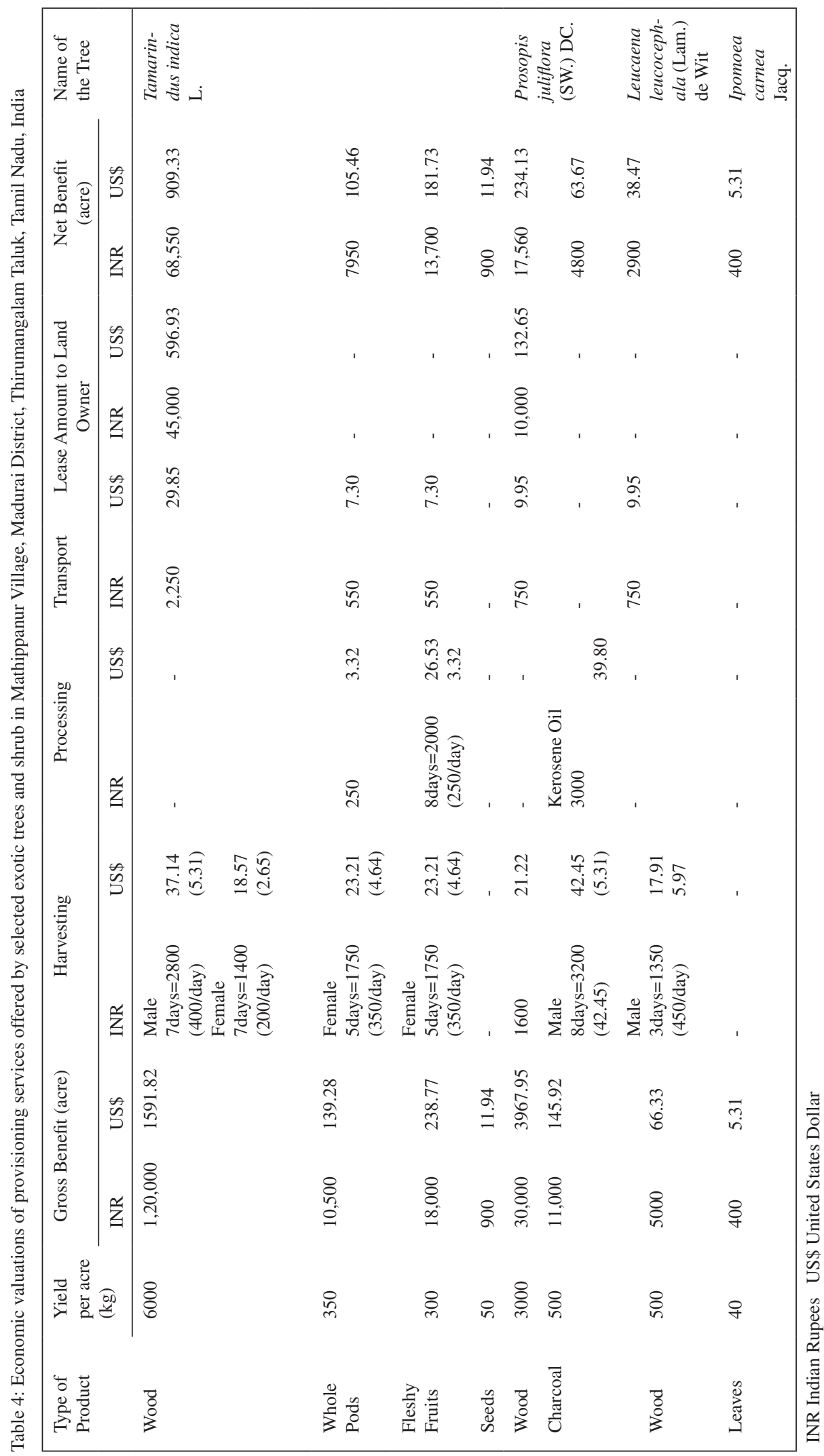


an acre was significantly high in A. indica $(3919.7 \pm 363.39$ $\mathrm{kg}$ carbon/acre) followed by $T$. indica and the exotic species P. juliflora (Fig. 4). The woody plant Prosopis proliferation in grasslands of Texas resulted in the enhancement of carbon stock from 15 to 24 times greater than grasslands (Hibbard et al. 2003).

Air purification: The people in the study area realized the air purification property and feeling of freshness under $A$. indica. M. tinctoria was also reported for its high air pollution tolerance index. The study report of Krishnaveni et al. (2014) revealed the air pollution tolerance index of these two plants in Yercaud, Tamil Nadu.

\section{Supporting Services}

Understory herbaceous species density: There were eight different herbaceous plant species recorded under the canopy of selected plant species. Among the eight different herbs, the density of grasses Cynodon dactylon, Cyperus rotundus, and Cynodon spp. were higher than other species (Table 5). The mean density of herbaceous species was less under the canopy of the exotic species I. carnea $(2.79 \pm$ $\left.0.78 / \mathrm{m}^{2}\right)$ and P. juliflora $\left(3.5 \pm 1.37 / \mathrm{m}^{2}\right)$ when compared to other species. Trees have shading effects due to their broad spreading crown and some of the trees have allelopathic effects. The growth and biomass production of herbaceous plant species were mainly affected by the shading effect (Frost \& Edinger 1991).

Soil quality parameters and microbial biomass carbon: The soil quality parameters of selected plants are given in Table 6. Soil bulk density above $1 \mathrm{~g} . \mathrm{cm}^{-3}$ has an influence on soil microbial community and their functions ( $\mathrm{Li}$ et al. 2002). But the maximum soil bulk density of $0.08{\mathrm{~g} . \mathrm{cm}^{-3}}^{-3}$ was recorded under $A$. indica tree canopy. It shows the little inhibitory effect of $A$. indica. It had low microbial biomass carbon and soil organic carbon when compared to other species (Diaz-Ravina et al. 1988). But the soil under T. indica had high organic carbon $(22.60 \pm 0.26 \%)$ and organic matter $(87.12 \pm 1.01 \%)$ and had a high soil respiration rate. A similar kind of observation was made by Faust et al. (2015). There were no significant differences in moisture content (\%) in the soil with selected plant species.

Nests of birds and animals: The number of nests laid by birds and animals on A. indica $(4.6 \pm 0.88)$ was comparatively higher than other species (Fig. 5). Crow and Crane species build their nests on these trees. Squirrels prefer to construct their nests only on M. tinctoria and P. juliflora. There were

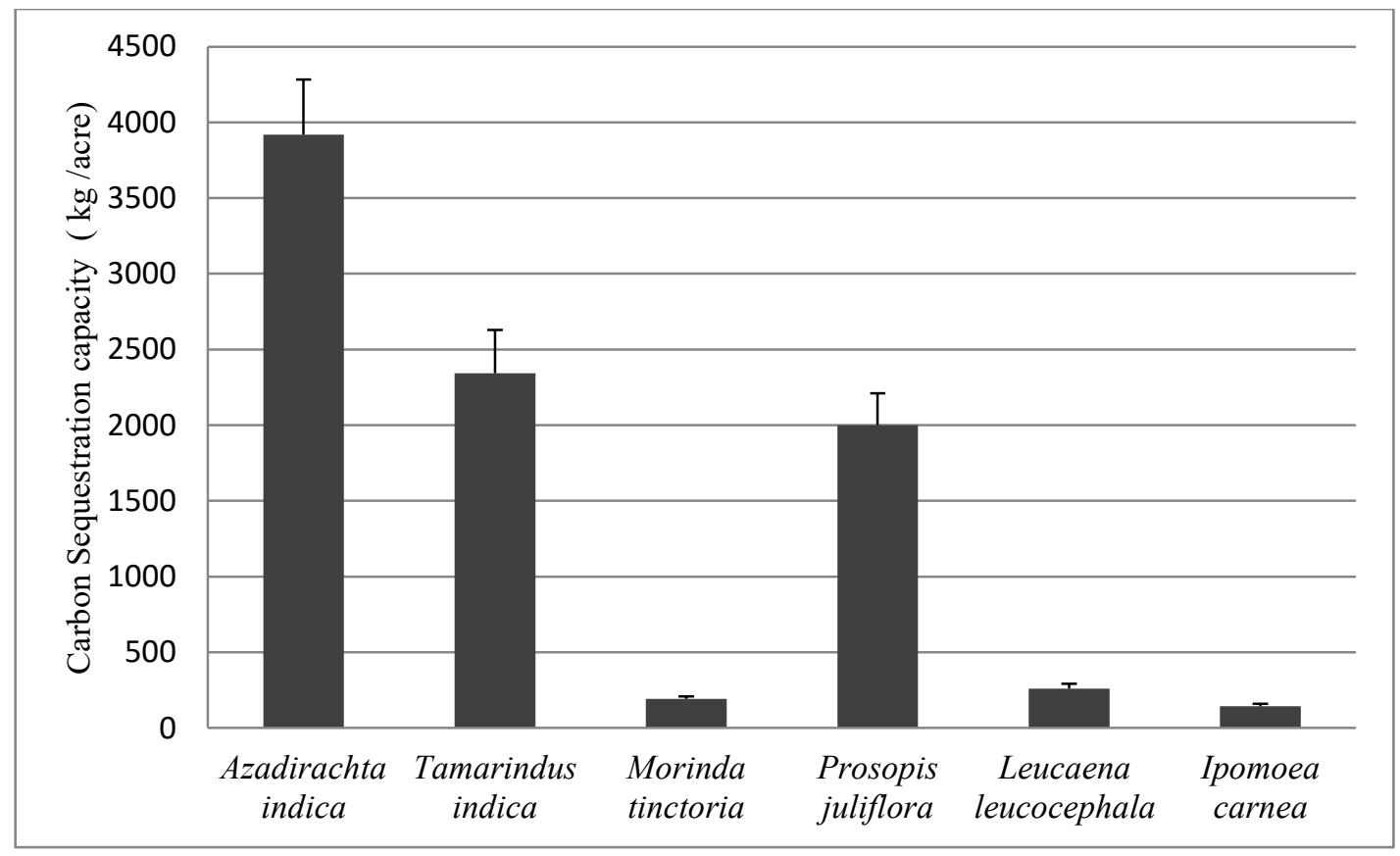

Fig.4: Carbon sequestered ( $\mathrm{kg} / \mathrm{acre})$ in the biomass of selected native and exotic plant species in an acre at Mathippanur Village, Thirumangalam Taluk, Madurai District, Tamil Nadu, India Values - Mean \pm SE 
Table 5: Density of herbaceous species under the canopy of selected native and exotic plant species in Mathippanur Village, Thirumangalam Taluk, Madurai District, Tamil Nadu, India

\begin{tabular}{|c|c|c|c|c|c|c|c|}
\hline $\begin{array}{l}\text { S. } \\
\text { No. }\end{array}$ & Name of the Species & $\begin{array}{l}\text { Azadiarachta } \\
\text { indica A. Juss. }\end{array}$ & $\begin{array}{l}\text { Tamarindus } \\
\text { indica } \mathrm{L} \text {. }\end{array}$ & $\begin{array}{l}\text { Morinda } \\
\text { tinctoria } \\
\text { Roxb. }\end{array}$ & $\begin{array}{l}\text { Prosopis juliflora } \\
\text { (SW.) DC. }\end{array}$ & $\begin{array}{l}\text { Leucaena } \\
\text { leucocephala (Lam.) } \\
\text { de Wit }\end{array}$ & $\begin{array}{l}\text { Ipomoea } \\
\text { carnea } \\
\text { Jacq. }\end{array}$ \\
\hline 1 & Pedalium murex $\mathrm{L}$. & 5.33 & 5.67 & 8 & 4.33 & 7 & 1.33 \\
\hline 2 & Cynodan spp. & 7 & 7.67 & 6.67 & 8.33 & 7 & 4.67 \\
\hline 3 & Cyperus rotundus $\mathrm{L}$. & 6 & 10.3 & 5.33 & 10 & 5.33 & 6 \\
\hline 4 & Cleome gynandra $\mathrm{L}$. & 4.33 & ---- & 6 & ---- & ---- & 3.67 \\
\hline 5 & Cynodan dactylon (L.) Pers. & 7 & 9.67 & 5.67 & 2.67 & 5.67 & 4 \\
\hline 6 & Acalypha indica $\mathrm{L}$. & 4.67 & ---- & 9.33 & 2.67 & 9.33 & ---- \\
\hline 7 & Tephrosia purpurea (L.) & 6 & 7.33 & 8 & --- & 6 & 2.67 \\
\hline 8 & Eranthemum spp. (L.) & 6.67 & 4.33 & ---- & --- & 6.67 & ---- \\
\hline
\end{tabular}

Values - Mean \pm SE. Different letters indicate significant differences among the mean values within a column at $\mathrm{p}<0.05$ level

Table 6: Soil quality parameters of selected native and exotic plant species in Mathippanur Village, Thirumangalam Taluk, Madurai District, Tamil Nadu, India

\begin{tabular}{|c|c|c|c|c|c|c|c|}
\hline S. No. & Name of the Species & $\begin{array}{l}\text { Bulk Density } \\
\left(\mathrm{g} / \mathrm{cm}^{3}\right)\end{array}$ & $\begin{array}{l}\text { Soil Moisture } \\
(\%)\end{array}$ & $\begin{array}{l}\mathrm{O} \text { r g a n i c } \\
\text { Carbon }(\%)\end{array}$ & $\begin{array}{l}\text { Organic Matter } \\
(\%)\end{array}$ & $\begin{array}{l}\text { Soil Respiration } \\
\left(\mathrm{mg} / \mathrm{hr} / \mathrm{m}^{2}\right)\end{array}$ & $\begin{array}{l}\text { Microbial } \\
\text { Biomass } \\
\text { Carbon (\%) }\end{array}$ \\
\hline 1 & $\begin{array}{l}\text { Azadirachta indica A. } \\
\text { Juss. }\end{array}$ & $0.08 \pm 0.002^{\mathrm{c}}$ & $7.45 \pm 0.57^{\mathrm{a}}$ & $\begin{array}{l}12.20 \pm \\
1.12^{\mathrm{a}}\end{array}$ & $47.03 \pm 4.34^{\mathrm{a}}$ & $\begin{array}{l}21.23 \pm \\
2.86^{\mathrm{b}}\end{array}$ & $\begin{array}{l}3.16 \pm \\
0.49^{\mathrm{a}}\end{array}$ \\
\hline 2 & Tamarindus indica $\mathrm{L}$. & $\begin{array}{l}0.079 \pm \\
0.005^{\mathrm{c}}\end{array}$ & $5.96 \pm 0.77^{\mathrm{a}}$ & $\begin{array}{l}22.60 \pm \\
0.26^{\mathrm{d}}\end{array}$ & $87.12 \pm 1.01^{\mathrm{d}}$ & $\begin{array}{l}105.57 \pm \\
4.71^{\mathrm{d}}\end{array}$ & $\begin{array}{l}7.23 \pm \\
0.38^{\mathrm{b}}\end{array}$ \\
\hline 3 & $\begin{array}{l}\text { Morinda tinctoria } \\
\text { Roxb. }\end{array}$ & $\begin{array}{l}0.06 \pm 0.0007 \\
\mathrm{~b}\end{array}$ & $6.34 \pm 1.28^{\mathrm{a}}$ & $\begin{array}{l}17.30 \pm \\
0.52^{c}\end{array}$ & $\begin{array}{l}66.69 \pm 2.03 \\
\mathrm{bc}\end{array}$ & $\begin{array}{l}89.33 \pm \\
2.87^{\mathrm{d}}\end{array}$ & $\begin{array}{l}6.7 \pm \\
0.55^{b}\end{array}$ \\
\hline 4 & $\begin{array}{l}\text { Prosopis juliflora } \\
\text { (SW.) DC. }\end{array}$ & $\begin{array}{l}0.071 \pm \\
0.0005^{\mathrm{bc}}\end{array}$ & $7.08 \pm 0.25^{\mathrm{a}}$ & $\begin{array}{l}15.60 \pm \\
0.45^{b}\end{array}$ & $60.14 \pm 1.76^{b}$ & $\begin{array}{l}15.18 \pm \\
4.32^{\mathrm{ab}}\end{array}$ & $\begin{array}{l}8.5 \pm \\
1.37^{\mathrm{b}}\end{array}$ \\
\hline 5 & $\begin{array}{l}\text { Leucaena leucocephala } \\
\text { (Lam.) de Wit }\end{array}$ & $0.05 \pm 0.0005$ & $8.30 \pm 2.66^{\mathrm{a}}$ & $\begin{array}{l}18.70 \pm \\
0.26^{\mathrm{c}}\end{array}$ & $72.09 \pm 1.01^{\mathrm{c}}$ & $\begin{array}{l}47.15 \pm \\
2.06^{c}\end{array}$ & $\begin{array}{l}7.56 \pm \\
0.53^{b}\end{array}$ \\
\hline 6 & Ipomoea carnea Jacq. & $\begin{array}{l}0.073 \pm \\
0.0006^{\mathrm{b}}\end{array}$ & $7.33 \pm 1.05^{\mathrm{a}}$ & $\begin{array}{l}17.00 \pm \\
0.10^{\mathrm{b}}\end{array}$ & $\begin{array}{l}65.53 \pm 0.38 \\
\mathrm{bc}\end{array}$ & $\begin{array}{l}2.99 \pm \\
1.16^{\mathrm{a}}\end{array}$ & $\begin{array}{l}9.4 \pm \\
0.53^{b}\end{array}$ \\
\hline
\end{tabular}

Values - Mean \pm SE. Different letters indicate significant differences among the mean values within a column at $\mathrm{p}<0.05$ level

no nests observed on L. leucocephala and I. carnea. The study reports of Chandrasekaran et al. (2014) implied that the tree species influence the reproductive success of the birds in wetland namely Vettangudi birds sanctuary, south India. The birds prefer to build their nests on the native tree Acacia indica.

Cultural services: The T. indica and A. indica have a large and extended crown. They offer shade and are used as shadow trees. They are also considered as a site for recreation and conducting meetings in villages. The people also recorded the warmness effect of $T$. indica and feeling of freshness by A. indica.

Disservices: People pointed out the release of heat by $T$. indi$c a$ and the mechanical disturbances by P. juliflora (Mwangi \&
Swallow 2008). Above all, the trees provide space for snakes and harmful insects and it was registered as a negative service by the people of the study area, Mathippanur.

\section{Services of Native and Exotic Species}

In general, there are reports pointed out that invasive weeds threaten biodiversity by displacing native species and disrupting community structure (Sala et al., 2000). Exotic species tend to alter the natural cycles and they decrease water quality in degraded wetlands in Spain (Angeler et al. 2002). However, there were not many significant differences recorded on soil moisture percentage under both native and exotic invasive species in the study area. The tremendous productivity and other services by exotic species were recorded. 
The results exemplify that both native and exotic plant species have financial and ecological significance. People who belong to different economic groups such as landowners, tenants, and laborers get revenue from the plants. The removal of exotic species is not advisable and its removal may induce a disturbance in the resilience of an ecosystem. People should be educated to be aware of unused valuable tree services (Davies et al. 2017). Monetary benefits provided by these plants can be enhanced through an effective management strategy.

\section{Management Strategies suggested for Ecosystem Welfare and Socio-Economic Upliftment}

The establishment of Plantation by the Government is the possible method to make use of uncultivable fallow land (around 300 acres) and barren land (around 250 acres) in the study area. The plantation should be mixed tree plantations with A. indica, T. indica M. tinctoria, and L. leucocephala. The plantations should contain combinations of these species with a minimum number of 40 to 100 per acre. I. carnea may not be included in the plantation because it prefers to grow in water-logged soil.

P. juliftroa is suitable for barren land and it is able to improve the soil $\mathrm{pH}$ and nutrient properties. It has already been proved that the plantations of $P$. juliftroa improved productivity of highly degraded sodic soil (Bhojvoid et al. 1996) and soil organic carbon and nitrogen were increased due to the growth of $P$. juliftroa in alkali soil (Singh 1996). Once the physico-chemical property of soil in barren land is enhanced, other trees can be planted.

Plantations should be managed by the Government. Specially trained personnel appointed by the Government can guide the people in pruning, weeding, adding nutrient supplements, and irrigation of plantation fields.

\section{CONCLUSION}

The tree species offer tremendous services to the ecosystem and human beings. The sustainable management of tree services and land will be achieved by means of establishing mixed plantations of the selected tree species. The plantations will assist in land utilization, conservation of soil health, nutrient cycling, air purification, and carbon sequestration along with offering employment opportunities and income to the local inhabitants. This will also provide an opportunity for people's participation in resource management and conservation.

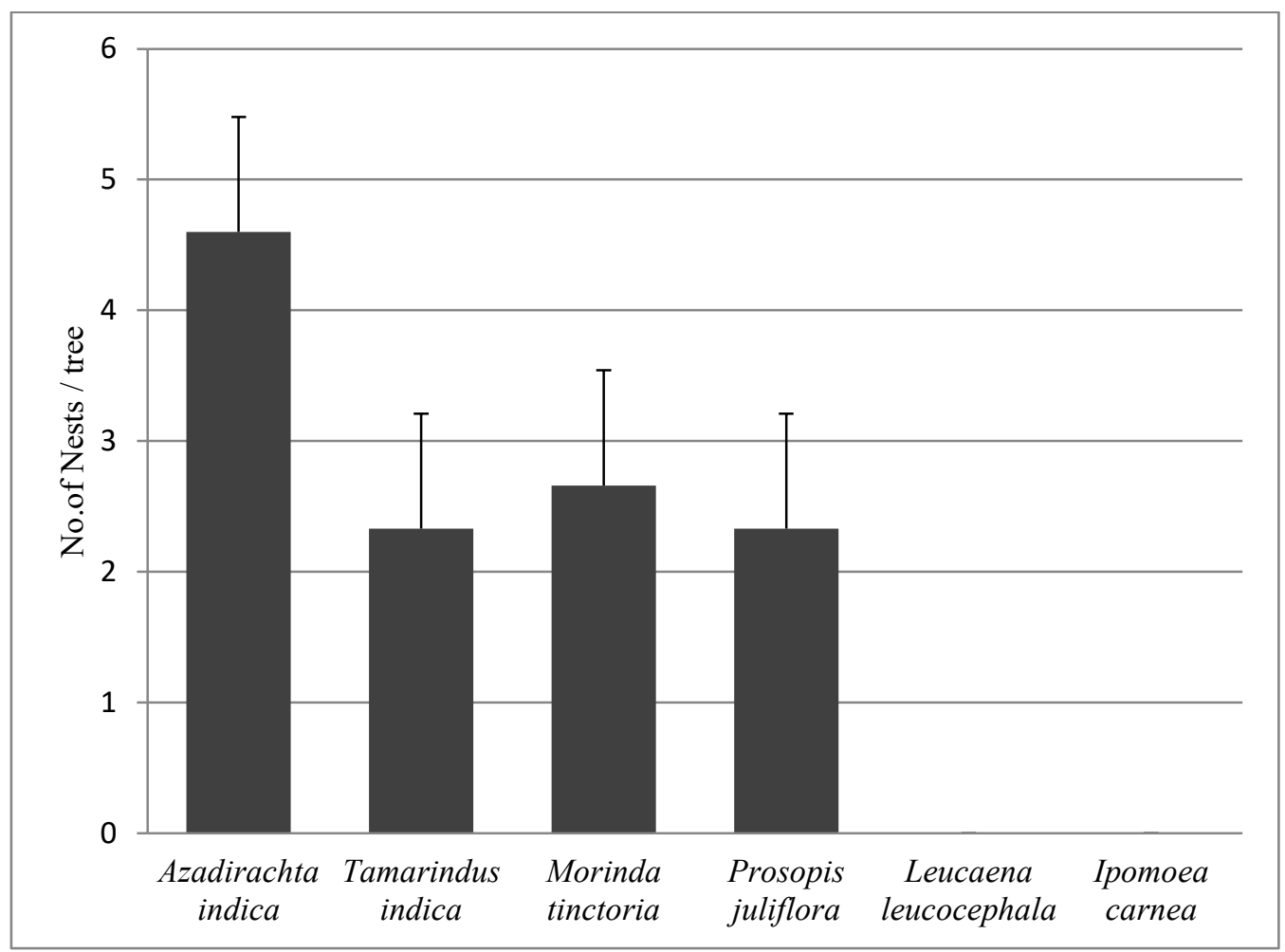

Fig. 5: Nests of birds and animals supported by selected native and exotic plant species in Mathippanur Village, Thirumangalam Taluk, Madurai District, Tamil Nadu, India Values - Mean \pm SE 


\section{ACKNOWLEDGEMENT}

We would like to thank Mr. Joyson Joe Jeevamani, National Centre for Sustainable Coastal Management, Chennai for his timely help and valuable suggestions for the completion of work.

\section{REFERENCES}

Anderson, J.M. and Ingram, J.S.I. 1993. Soil Organic Matter and Organic Carbon. In: Anderson, J.M. and Ingram, J.S.I. (eds.) Tropical Soil Biology and Fertility: A Handbook of Methods. Second edition, CAB International, Wallingford, U.K., pp. 62-66.

Anderson, J.P.E. 1982. Soil Respiration. In: Page, A.L., Miller, R.H. and Keeney, D.R. (eds.) Methods of Soil Analysis, Part 2. American Society of Agronomy, Inc., Soil Science Society of America, Inc., Madison Wisconsin, pp. 831-871.

Angeler, D.G., Alvarez-Cobelas, M., Sanchez-Carrillo, S. and Rodrigo, M.A. 2002. Assessment of exotic fish impacts on water quality and zooplankton in a degraded semi-arid floodplain wetland. Aquat. Sci., 64: 76-86.

Bennett, E.M., Peterson, G.D. and Gordon, L.J. 2009. Understanding relationships among multiple ecosystem services. Ecol Lett., 12(12): 1394-404.

Bhojvoid, P.P., Timmer, V. R. and Singh, G. 1996. Reclaiming sodic soil for wheat production by Prosopis juliflora (Swartz) DC afforestation in India. Agrofor.Syst., 34: 139-150.

Bokrezion, H. 2008. The Ecological and Socio-economic Role of Prosopis juliflorain in Eritrea: An analytical assessment within the context of rural development in the Horn of Africa, Ph.D Thesis, Mainz.

Chandrasekaran, S., Saraswathy K., Saravanan, S., Kamaladhasan, N. and Arun Nagendran, N. 2014. Impacts of Prosopis juliflora on nesting success of breeding wetland birds at Vettanguudi bird sanctuary. South India. Curr. Sci., 106(5): 676-678.

Chave, J., Andalo, C., Brown, S. and Cairns, M.A. 2005. Tree allometry and improved estimation of carbon stocks and balance in tropical forests. Oecologia, 145: 87-99.

Chee, Y.E. 2004. An ecological perspective on the valuation of ecosystem services. Biol. Conserv., 120: 549-565.

Costanza, R., d'Arge, R., de Groot, R., Farber, S., Grasso, M., Hannon, B., Limburg, K., Naeem, S., O’Neill, R., Paruelo, J., Raskin, R., Sutton, P. and van den Belt, M. 1997. The value of the world's ecosystem services and natural capital. Nature, 387: 253-260.

Daily, G.C. 1997. Introduction: What are ecosystem services? In: Daily, G.C. (ed.) Nature's Services: Societal Dependence on Natural Ecosystems. Island Press, Washington DC, pp. 1-10.

Davies, H.J., Doick, K.J., Hudson, M.D. and Schreckenberg, K. 2017. Challenges for tree officers to enhance the provision of regulating ecosystem services from urban forests. Environ. Res. 156, 97-107.

de Groot, R.S., Wilson, M.A. and Boumans, R.M.J. 2002. A typology for the classification, description, and valuation of ecosystem functions, goods, and services. Ecol Econ., 41: 393-408.

Diaz-Ravina, M., Caraballas, T. and Acea, M.J. 1988. Microbial biomass activity in four acid soils. Soil Biol. Biochem., 20: 817-823.
Faust, S., Hanisch, S., Buerkert, A. and Joergensen, R. G. 2015. Soil properties under manured Tamarindus indica in the littoral plain of south-western Madagascar. Arid Land Res Manag., 29(2): 167-179.

Frost W.E. and Edinger S.B. 1991. Effects of tree canopies on soil characteristics of annual rangeland. J. Range Manag., 44: 286-288.

Godoy, R., Lubowski, R. and Markandya, A. 1993. A method for the economic valuation of non-timber forest products. Econ. Bot., 47: 220-233.

Hibbard, K.A., Schimel, D., Archer, S., Ojima, D. S. and Parton, W. 2003. Grassland to woodland transitions: Integrating changes in landscape structure and biogeochemistry. Ecol Appl., 13: 911-926.

Ilukor, J., Rettberg, S., Treydte, A. and Birner, R. 2016. To eradicate or not to eradicate? Recommendations on Prosopis juliflora management in Afar, Ethiopia, from an interdisciplinary perspective. Pastoralism: Res. Pol. \& Pract. 6(14): 1-8.

Jackson, M.L. 1973. Soil Chemical Analysis. Prentice of Hall of India Ltd., New Delhi.

Krishnaveni, M., Kalimuthu, R., Ponraj, K., Lavanya, K., Magesh, P. and JasbinShyni, G. 2014. Air pollution tolerance index assessment of Yercaud roadside plants. Int. J. Pharm. Sci. Rev. Res., 6(5): 362-4.

Li, C., Ma, B. and Zhang, T.Q. 2002. Soil bulk density effects on soil microbial populations and enzyme activities during the growth of maize (Zea mays L.) planted in large pots under field exposure. Can. J. Plant Sci., 82(2): 147-154.

Millennium Ecosystem Assessment (MEA). 2003. Ecosystems and Human Wellbeing: A Framework for Assessment. Island Press, Washington DC.

Mwangi, E. and Swallow, B. 2008. Prosopis juliflora invasion and rural livelihoods in the Lake Baringo area of Kenya. Conserv. Soc., 6: 130-140.

Ogah, E.O., Omoloye, A.A., Nwilene, F.E. and Nwogbaga, A.C. 2011. Effect of neem seed kernel extracts in the management of rice stem borers in the field in Nigeria. Nig J. Biotech., 23: 13-21.

Orwa, C., Mutua, A., Kindt, R., Jamnadass, R. and Anthony, S. 2009. Agroforestree Database: A tree reference and selection guide version 4.0. World Agroforestry Centre, Kenya

Pimentel, D., McNair, S., Janecka, J., Wightman, J., Simmonds, C., O'Connell., C., Wong, E., Russel, L., Zern, J., Aquino, T., and Tsomondo, T. 2001. Economic and environmental threats of alien plant, animal, and microbe invasions. Agric Ecosyst Environ., 84(1): 1-20.

Roeland, S., Moretti, M., Amorim, J.H., Branquinho,C., Fares, S., Morelli, F., Niinemets, U., Paoletti, E., Pinho,P., Sgrigna, G., Stojanovski, V., Tiwary, A., Sicard, P. and Calfapietra, C. 2019. Towards an integrative approach to evaluate the environmental ecosystem services provided by urban forest. J. For. Res., 30: 1981-1996.

Sala, O.E., Chapin, F.S., Armesto, J.J., Berlow, E. and Bloomfield, J. 2000. Global biodiversity scenarios for the year 2100. Science, 287 : 1770-1774.

Scholes, R.J. and Noble, I.R. 2001. Storing carbon on land. Science, 294: 1012-1013.

Singh, G. 1996. Effect of site preparation techniques on Prosopis juliflora in an alkali soil. Forest Ecol Manag., 80: 267-278.

Vance, E.D., Brookes, P.C. and Jenkinson, D.S. 1987. An extraction method for measuring soil microbial biomass carbon. Soil Biol. Biochem., 19: 703-707.

Whittaker, R.H. 1961. Estimation of net primary production of forest and shrub communities. Ecol, 42: 177-180. 